\title{
Det politiska etablissemangets strategier gentemot högerpopulistiska partier
}

\author{
Björn Fryklund \& Sigrid Saveljeff
}

SAMMANDRAG: Mellan 2002 och 2018 utvecklades Sverigedemokraterna från ett marginellt parti till en politisk kraft att räkna med: partiet fick cirka I8 procent av rösterna i riksdagsvalet 20I8. Björn Fryklund och Sigrid Saveljeffs artikel är en analys av Socialdemokraternas och Moderaternas förhållningssätt till Sverigedemokraterna under denna period. En utgångspunkt är den amerikanska statsvetaren Bonnie Meguids PSO-teori (position, salience, ownership), vilken urskiljer tre huvudsakliga strategier som dominerande partier kan tillämpa mot nischpartier: avvisande, konvergerande och divergerande. Författarna visar att trovärdighet och demokratisk legitimitet har haft stor betydelse för vilka strategier $\mathrm{S}$ och $\mathrm{M}$ har valt. Det finns ett demokratiskt dilemma: väljarnas efterfrågan på partier med högerpopulistisk dagordning skapar motsvarande tillgång, och förr eller senare uppstår en konflikt med den liberala demokratins grundläggande värden. Det skapar ett strategiskt dilemma för de etablerade partierna: de tvingas balansera mellan att sträva mot sina egna mål och att hantera det demokratiska dilemmat. I Sverige har det demokratiska dilemmat blivit allt mer underordnat det strategiska dilemmat.

NYCKELORD: högerpopulism; migration; Sverigedemokraterna; PSO-teorin; politiska strategier; avvisande, divergens och konvergens.

PUBLICERINGSHISTORIK: Originalpublicering.

BJÖRN FRYKLUND är professor i sociologi vid Malmö universitet.

E-POSTADRESS: bjorn.fryklund@mau.se

SIGRID SAVELJEFF är filosofie doktor i etnicitet vid Högskolan Dalarna.

E-POSTADRESS: ssf@du.se

FÖRSLAG PÅ KÄLLANGIVELSE:

Fryklund, Björn \& Sigrid Saveljeff (2019) "Det politiska etablissemangets strategier gentemot högerpopulistiska partier", i Arkiv. Tidskrift för sambällsanalys, nr Io, s. 33-70. DOI: https://doi.org/IO.I3068/2000-6217.I0.2

(C) Författarna/Arkiv förlag \& tidskrift 2019 (publicerad 20 mars 2019)

Artikeln distribueras enligt en upphovsrättslicens från Creative Commons:

Erkännande-Ickekommersiell-IngaBearbetningar 3.o Unported, som medger fri ickekommersiell användning och spridning i oförändrat skick så länge källan anges. 
Arkiv. Tidskrift för samhällsanalys är en sakkunniggranskad vetenskaplig tidskrift för samhällsvetenskap och historia. Samtliga artiklar publiceras fritt tillgängliga på:

$$
\text { www.tidskriftenarkiv.se }
$$

Beständig länk, DOI: https://doi.org/IO.13068/2000-62I7

Den här artikeln finns tillgänglig i följande format:

PDF: via beständig länk, DOI: https://doi.org/IO.13068/2000-62I7.IO.2 TRYCK: ingår i bokutgåva av numret, ISBN: 978 9I 79243272

Grafisk utformning och sidnumrering är identisk i pdf och tryck.

Samtliga artiklar i nr ıo (2019) nås via beständig länk, DOI: https://doi.org/IO.13068/2000-6217.10

Arkiv. Tidskrift för samhällsanalys ISSN: 2000-62I7 (för elektronisk resurs) ISSN: 2000-6225 (för tryckta nummer)

ges ut av

Stiftelsen Arkiv för främjande och spridning av samhällsvetenskaplig och historisk forskning

\author{
genom \\ Arkiv förlag \& tidskrift \\ Box 1559 \\ SE-22I OI Lund \\ BESÖK: L Gråbrödersg 3 c, ipg \\ TEL: 046-I3 3920
}

ARKIV FÖRLAG: arkiv@arkiv.nu·www.arkiv.nu

TIDSKRIFTENARKIV: red@tidskriftenarkiv.se·www.tidskriftenarkiv.se

ANSVARIg UTGIVARE \& CHEFREDAKTÖR: Sven Hort

ADMINISTRATIV REDAKTÖR: David Lindberg Redaktörer: Paavo Bergman, Per Dannefjord, Lisa Kings,

Zhanna Kravchenko, Anna-Maria Sarstrand Marekovic 


\title{
Det politiska etablissemangets strategier gentemot högerpopulistiska partier
}

\author{
BJÖRN FRYKLUND \& SIGRID SAVELJEFF
}

\section{Inledning. Ett nytt politiskt landskap?}

I samband med valet 2018 stod det klart att Sverigedemokraterna, ett svenskt högerpopulistiskt parti, erhållit närmare I8 procent av väljarnas röster och var det parti som gått framåt starkast bland samtliga partier. Sverigedemokraternas väljarframgångar i valet 2018 har väckt starka reaktioner, framför allt beroende på att partiet bygger sin politiska agenda på kritik av det politiska etablissemanget grundat på en stram och mycket återhållen migrationspolitik.

I den här artikeln studerar vi utvecklingen närmare, dock inte genom att granska Sverigedemokraternas politiska retorik utan genom att fokusera på hur de etablerade partierna över tid bemött den nya politiska utmanaren. Hur har Socialdemokraterna och Moderaterna hanterat närvaron av Sverigedemokraterna? Vilka strategier använder de etablerade partierna för att bemöta Sverigedemokraterna, ett parti som alltsedan valet 2006 erhållit alltmer väljarstöd och som inte minst lockat väljare från såväl Socialdemokraterna som Moderaterna? Och än viktigare: Finns det tecken på att de etablerade partierna försöker närma sig Sverigedemokraternas väljarbas?

För att besvara dessa frågor har vi undersökt hur Socialdemokraterna och Moderaterna har bemött Sverigedemokraterna under perioden 2002-2018 och kopplat detta till en teoretisk modell. Samtidigt som vi 
ARKIV | NR IO | VALET 2OI8

analyserar en konkret situation (den svenska utvecklingen) får vi alltså möjlighet att testa den teoretiska modellen.

Kapitlet bygger i huvudsak på sekundärt empiriskt material kompletterat med en mindre del primärmaterial, och därutöver på en sammanslagning av forskning som vi tidigare genomfört.

\section{Vad är populism och högerpopulism?}

Vi har analyserat förändringar i det politiska systemet och det politiska läget i Sverige som en del av en övergripande förändring av det politiska mönstret i Europa 2002-20I8. Under denna tid har en ny politisk partifamilj erhållit allt större väljarstöd i hela Europa: högerpopulistiska partier (HP-partier). För att kunna diskutera denna politiska familj måste vi definiera begreppen "populism" och "högerpopulism".

I likhet med Cas Mudde och Cristóbal Rovira Kaltwasser (20I7) definierar vi populism som en ideologi som betraktar samhället som uppdelat i två delar vilka är varandras motsatser och till viss del antagonister: folket och den korrupta politiska eliten. Enligt populismen ska all politik vara ett uttryck för det sanna folkets vilja, inte det politiska etablissemangets (Mudde \& Rovira Kaltwasser 20I7).

Populismen har enligt Mudde och Rovira Kaltwasser en lättviktig kärna (eng. thin-centered), till skillnad från fascism, konservatism, socialism och liberalism, som har täta och tunga kärnor (eng. thickcentered), vilket innebär att populism framför allt framträder i förhållande till andra ideologier (Mudde \& Rovira Kaltwasser 20I7). Enligt Mudde och Rovira Kaltwasser kan populismen inte stå på egna ben som ideologi utan anpassar sig till andra ideologiers uttryck för att förstärka den egna linjen. På samma sätt som kameleonten anpassar sig till sin omgivning, växlar och förändras populismens uttryck med den nationella och samhälleliga kontexten (jfr Taggart 2000). Därmed kan den populistiska ideologin fyllas med olika innehåll (Mudde \& Rovira Kaltwasser 20I7).

Mot den bakgrunden menar vi att förändringar hos populistiska ideologier och populistiska partier bör analyseras med hänsyn till den ekonomiska, politiska och samhälleliga utvecklingen samt variabler som klass, folklighet, politisk kultur och nationalism (Fryklund \& Peterson 
198I; Fryklund 20I8). Låt oss diskutera dessa variabler närmare för att tydliggöra deras betydelse i sammanhanget.

Ens klasstillhörighet kan sägas främst avgöras av ens yrkestillhörighet (Esping-Andersen 1990; Olin Wright 1997; Goldthorpe 2007). Populistiska partier har en tendens att beteckna sig som klasslösa, som att de inte tillhör någon särskild samhällelig grupp. Samtidigt hävdar dessa partier att de representerar "vanligt folk" och deras intressen. Populistiska partier riktar ofta stark kritik mot partier som de anser bidrar till att skapa ett samhälle baserat främst på klasstillhörighet där vissa samhällsklassers intressen går före "vanligt folks".

Folklighet består av folkliga traditioner och folkliga appeller, det vill säga hänvisningar till dessa traditioner och till en motsättning mellan folket och makthavarna. Folkliga traditioner har utvecklats kring teman som nation, etnicitet, kultur, religion, politik, demokrati, arbete, familj, moral och social solidaritet, och de är djupt rotade i varje nation. När de etablerade och dominerande partiernas folkliga appeller vacklar, får populistiska appeller möjlighet att konkurrera om väljarna (Fryklund \& Peterson 198I; Fryklund, Kiiskinen \& Saveljeff 2007).

Politisk kultur är framför allt de konstruktioner som ligger till grund för välfärdsstaterna i Norden och Västeuropa (Bennich-Björkman 2008; Fryklund 2008). Vi menar att ett lands politiska kultur baseras på väljarnas konkreta avtryck på den politiska arenan. Den politiska kulturen är en hörnsten i det politiska landskapet och fyller de politiska argumenten med mening i och med att de knyts till kulturella, sociala och politiska institutioner.

Nationalism kan vara etniskt eller politiskt orienterad (Kohn 1944; Smith 1986). Inom ramen för den populistiska ideologin har demokrati (eller avsaknaden därav) en inbyggd etnisk nationell dimension som huvudsakligen handlar om kampen mellan folket och en diffus elit. Framför allt gäller kampen hur den sociala välfärden ska fördelas, och den ges en etnonationell dimension genom att individer med annan etnisk bakgrund än majoritetsbefolkningen exkluderas från välfärdsstrukturerna (etnonationell välfärdschauvinism).

Ovanstående definition av populism blir bara begriplig om det finns en opposition mot den, om "icke-populism" (eng. non-populism) exis- 
terar. Mudde och Rovira Kaltwasser anser att elitism och pluralism står i direkt motsättning till populism. Elitism är motsatsen till populism på grund av åsikten att politik uteslutande är till för eliten och att folket måste utestängas från den politiska sfären. Pluralism hyllar däremot mångfald och välkomnar denna folkets mångfald inom olika politiska sfärer (Mudde \& Rovira Kaltwasser 20I7).

Mudde och Rovira Kaltwasser urskiljer tre begrepp som ligger till grund för förståelsen av populism: "folket", "eliten" och "den allmänna viljan". Vi instämmer, och menar att dessa begrepp också är avgörande för att förstå utvecklingen av högerpopulistiska partier, inte minst i Sverige på senare år. Populistiska partier legitimerar sina mål och metoder genom att tilldela sig själva rollen som representanter för folket $\mathrm{i}$ motsättning till den korrupta eliten och det politiska etablissemanget. En viktig ingrediens i den populistiska retoriken och ideologin är att framhålla det påstådda hot som eliten riktar mot folket och förklara hur det ska hanteras. Eftersom de etablerade partierna enligt de populistiska partierna är en del av denna elit spelar de en viktig roll för den politiska diskursen och de populistiska partiernas agerande. För att förstå populism och populistiska partier måste vi alltså förstå deras motståndare. Folket, eliten och den politiska viljan är dessutom essentiella för att förstå de politiska strategier som de etablerade partierna tar till mot sina populistiska konkurrenter (Mudde \& Rovira Kaltwasser 20I7).

\section{Den populistiska utmaningen och krisen för det europeiska politiska systemet}

Politiska partier med tydlig högerpopulistisk profil har varit mer framgångsrika i Europa under de senaste årtiondena än under tidigare årtionden. I dag finns någon form av högerpopulistiskt parti representerat i så gott som vartenda europeiskt land. För att kunna diskutera den högerinriktade partifamiljen måste vi dock skilja mellan högerpopulistiska partier och extrema högerpartier inklusive fascistiska partier (se även Mudde 20IO, 20I4; Fryklund 20I5). Det är särskilt viktigt i ljuset av diskussionen om relationen mellan dessa partiers uppträdande på den politiska arenan och det som vissa forskare anser vara en kris för det europeiska politiska systemet (Goodwin 20I4; Mudde 20I3). 
Det finns tydliga skillnader i hur dessa två partifamiljer förhåller sig till parlamentarisk och representativ demokrati. Mudde (20I0) beskriver det populistiska högerpartiet som ett "patologiskt normalt traditionellt" parti. Han intar därmed en annan position än en betydande del av forskarsamhället gör, vilka i stället hävdar att HP-partier är "normal patologi”, precis som fascism och högerextremism. Mudde hävdar att denna tes inte håller för empirisk granskning. Några av de mest framträdande egenskaperna hos högerpopulistisk ideologi är enligt Mudde socialkonservatism, auktoritetstro och nationalism, vilka inte kan skiljas från ideologier och åsikter som finns hos majoriteten av väljarkåren. Faktum är att Mudde uppfattar dessa som en "radikalisering av normala värderingar. Därför bör den populistiska högern betraktas som patologisk normalitet och inte som normal patologi” (Mudde 20IO, s. II8I). $\mathrm{Vi}$ anser att Muddes förhållningssätt leder till intressanta insikter i de politiska strategier de dominerande etablerade partierna använder mot HP-partier, vilka i sin tur starkt kan påverka HP-partiernas potentiella framtida framgångar.

Högerextrema partier tenderar att växa under ekonomiska kriser, populistiska partier växer oftast i tider då ekonomin och de sociala välfärdssystemen är i god form, eller åtminstone inte i dålig form. Vi instämmer i denna slutsats, som också har fătt empiriskt och teoretiskt stöd av andra forskare i Europa (Mudde 20I3; Goodwin 20I4). Vi anser vidare att det är mer relevant att koppla HP-partiers tillväxt och framgång till perioder med djupgående politiska och kulturella kriser, snarare än till enstaka ekonomiska och sociala kriser.

Över hela Europa har HP-partier fått väljarnas stöd genom att ifrågasätta och kritisera ökningen av mångkulturella inslag i samhället och genom att företräda en politik som mer eller mindre uttalat strävar efter att utesluta utländska medborgare från välfärdssystemen. Partierna inriktar sig också på frågor med tydlig socialkonservativ och nationalistisk grund, och tar på sig rollen som folkets röst i kampen mot det politiska etablissemanget och eliten. Framgångarna för HP-partier i Europa kan ses som kritik från väljarna mot en samhällsutveckling präglad av globalisering, och närmare bestämt internationell migration. Vissa väljargrupper i såväl Sverige som andra europeiska länder har tydligt visat 
sitt missnöje med hur de dominerande etablerade partierna har bemött väljarkårens kritik av förändringar i samhället. Väljarkåren har också gett uttryck för känslan av att det politiska etablissemanget "är i otakt med väljarna" i sådana frågor (jfr Kiiskinen \& Saveljeff 20IO; Saveljeff 20II; Fryklund 20I5, 20I8). Slutligen återspeglas väljarkårens missnöje med de etablerade partiernas politiska program i det stadigt ökade väljarstödet för HP-partier i nationella val i hela Europa under de senaste åren (Fryklund 20I8).

\section{Högerpopulistiska partier - en utmaning för den liberala demokratin?}

$\mathrm{Vi}$ analyserar i det här kapitlet de dominerande och etablerade politiska partiernas strategier för att bemöta de högerpopulistiska partierna, och den analysen kan också kasta ljus över hur HP-partier har utvecklats. Analysen gäller svenska förhållanden men vi vidgar även perspektivet till övriga Norden och Europa.

HP-partier, såsom Sverigedemokraterna, tillhör en partifamilj som under de senaste årtiondena har ökat sitt väljarstöd i Europa genom en politisk dagordning med populistisk profil, kryddad med frispråkig kritik mot framväxten av mångkulturella samhällen och med tydligt fokus på införandet av mer restriktiv lagstiftning för invandring och flyktingmottagande.

Tidigare forskning (Kiiskinen \& Saveljeff 20IO; Saveljeff 20II; Fryklund 2015, 20I8) visar att närvaron av HP-partier kan ge upphov till ett dilemma som är nära förknippat med grundläggande demokratiska värderingar: väljarkårens efterfrågan på partier med högerpopulistisk dagordning skapar motsvarande tillgång, och den utvecklingen leder förr eller senare till en konflikt med den liberala demokratins grundläggande värden, såsom varje individs mänskliga rättigheter. I den konfliktzon som uppstår framträder det demokratiska dilemmat (Schain, Zolberg \& Hossay 2002; Eatwell 2004; Mouffe 2005; Fryklund, Kiiskinen \& Saveljeff 2007; Mudde 2007; Kiiskinen \& Saveljeff 20IO; Saveljeff 20II).

HP-partier agerar, till skillnad från extremhögern, inom ramarna för parlamentarisk representativ demokrati. Men när de och deras politiska program har etablerat sig kan deras närvaro inom det demokratiska ram- 
verket leda till en inskränkning av vissa individers medborgerliga rättigheter. I det avseendet kan närvaron av HP-partier utmana toleransen och pluralismen inom den liberala demokratin (Schain, Zolberg \& Hossay 2002; Capoccia 2004; Eatwell 2004; Mouffe 2005; Mudde 2007; Kiiskinen \& Saveljeff 20IO; Saveljeff 20II; Fryklund 20I5, 20I8).

Det politiska etablissemanget tvingas att ta itu med det demokratiska dilemmat. I flerpartisystem är strategier mot andra politiska partier inget ovanligt i sig, men det demokratiska dilemmat gör att strategierna inte är självklara när det gäller HP-partier. Den strategi som har använts mest av de dominerande etablerade partierna i Europa har varit att isolera och stänga ute HP-partier (Downs 200I, 2002; Meguid 2008; jfr Kiiskinen \& Saveljeff 20IO). Det kan visserligen ses som en rationell lösning för att styra och minska konkurrensen från motståndarna, men tenderar att uppfattas som odemokratiskt av väljarkåren eftersom det förvägrar ett demokratiskt valt parti politiskt inflytande eller tillträde till den politiska arenan.

Det demokratiska dilemmat tillför därmed fler och mer komplexa dimensioner till den strategiska processen. Att undersöka de etablerade partiernas strategiska förhållningssätt till HP-partier är därför ett nödvändigt bidrag till den viktiga diskussionen om hur etablerade partier strategiskt hanterar partier som historiskt sett betraktats som paria (Downs 200I; Bale 2003; de Lange 2008; Kiiskinen \& Saveljeff 20IO; Fryklund 20I8; jfr Andersson m.fl. 20I7).

I fokus för denna artikel står Socialdemokraternas och Moderaternas strategiska förhållningssätt till Sverigedemokraterna. Till följd av de senaste årens stadigt ökade väljarstöd för Sverigedemokraterna, först i kommunalvalen, senare i riksdagsvalen 2006, 20I0 och 2014 och senast i valet 20I8, är partiet nu en stark politisk motståndare som de dominerande etablerade partierna har att förhålla sig till och bemöta. Det är inte längre möjligt att betrakta Sverigedemokraterna som ett tillfälligt politiskt fenomen - även om tidigare forskning visat att sådana resonemang var vanligt förekommande bland de dominerande etablerade partierna i Sverige under relativt lång tid (Kiiskinen \& Saveljeff 20IO; Saveljeff 20II; Fryklund 20I5, 20I8). 
ARKIV | NR IO | VALET 2OI8

\section{Den svenska kontexten ur ett europeiskt perspektiv}

I Sydsvenskan den I3 maj 2018 skrev Per T. Ohlsson:

Egentligen var det bara en fråga om när.

Den senaste veckans inrikespolitiska diskussion har kretsat kring Socialdemokraternas skärpta migrationspolitik och hur invandringsrelaterade problem dominerade förra söndagens partiledardebatt i SVT.

Plötsligt, eller kanske inte så plötsligt, har landets största parti tagit ytterligare sjumilakliv i restriktiv riktning. Detta har öppnat för en flyktingpolitisk "järntriangel" bestående av Socialdemokraterna, Moderaterna och Sverigedemokraterna, tre partier som tillsammans förfogar över en förkrossande riksdagsmajoritet.

$[---]$

Vad är skälet till den socialdemokratiska kanonaden av hårda tag? Det stavas förstås Sverigedemokraterna och i någon mån Moderaterna, två partier som i väljarnas ögon har större trovärdighet i de frågor som nu klättrar på den politiska agendan: migration samt lag och ordning.

I Sverige saknades det länge en framgångsrik högerpopulism, och sedan sin uppkomst har den svenska högerpopulismen bemötts med fientlighet eller kraftigt avståndstagande i det politiska systemet (Fryklund 20I5, 20I8). Det svenska undantaget ska jämföras med en lyckad populism i Europa de senaste femtio åren, vilken där har medfört att anpassningen till denna har hunnit långt.

Vi ger här bara preliminära svar på den viktiga och svåra frågan hur partier som verkar utmana den liberala demokratins centrala aspekter behandlas på den politiska arenan. Ett nytt politiskt landskap kommer dock att uppstå, ett landskap där Sverigedemokraterna spelar en central roll inte minst i fråga om hur politiska majoriteter kan uppstå och bildas. Vi bedömer att utvecklingen i Sverige inom kort kommer att likna den i våra grannländer (Fryklund 20I8). Den komplicerade parlamentariska situationen efter riksdagsvalet 2018 pekar tydligt i den riktningen.

Sedan slutet av 2015 har diskussionen om hur röstmajoriteter uppstår i det svenska politiska systemet intensifierats märkbart. Diskussionen har i första hand gällt hur en fungerande riksdagsmajoritet kan uppnås, i ljuset av Sverigedemokraternas växande väljarstöd. Ämnet blev extra aktuellt efter riksdagsvalet 2018 och under de efterföljande diskussionerna 
om möjliga regeringsbildningar. Medan de två största och dominerande partierna ständigt konfronterat varandra om hur en fungerande majoritet ska byggas (under senare år har även övriga etablerade partier gett sig in mer aktivt i debatten), har de samtidigt genomfört dramatiska ideologiska förändringar i sina migrationspolitiska program, från en relativt öppen och generös linje till en sluten och restriktiv som snabbt rör sig i riktning mot Sverigedemokraternas migrationspolitik.

Paradoxalt nog har de dominerande etablerade partierna gjort officiella uttalanden med budskapet att Sverigedemokraterna inte är en politisk motståndare att ta på allvar och att det aldrig kommer att bli aktuellt att samarbeta eller samtala med dem. Ett sådant demoniserande förhållningssätt hos de etablerade partierna bygger huvudsakligen på en hegemonisk antirasistisk norm i det svenska samhället. Vi menar att vi kanske ser början till slutet för denna norm. Inte minst med tanke på att de första tecknen på avvikande röster i konsensuskören har hörts allt oftare i de senare årens offentliga debatt (Fryklund 2015, 2018).

Varför har det tagit så lång tid för ett uttalat högerpopulistiskt parti att uppnå varaktig framgång i Sverige? Socialdemokraternas historiskt starka ställning har lett till en unik politisk och ideologisk hegemoni i Sverige i form av vittgående konsensus kring svensk demokrati och den svenska välfärdsmodellen. Frånvaron av avgörande politiska och ideologiska frågor som kunnat ena eller splittra befolkningen har också spelat en roll. Sveriges ekonomi har varit i god form (och är det fortfarande). Även välfärdssystemet har fungerat bra, åtminstone fram till början av I990-talet. Dessa förutsättningar verkade ha gjort det svenska samhället och dess politiska kultur så gott som immunt mot högerpopulism. I våra nordiska grannländer och flera andra europeiska länder vann däremot högerpopulistiska partier större inflytande under tiden fram till slutet av I990-talet (Taggart 1996; Kitschelt 1997; Rydgren 2002, 2017; Fryklund 2008, 2018).

Den svenska immuniteten verkade dock upphöra när politiska och sociala förhållanden förändrades på 200o-talet, vilket gav HP-partier möjlighet att få ett långvarigt väljarstöd även här. Tidigare forskning har dock visat att xenofoba tendenser eller betoning av immigrant- och flyktingfrågor inte helt kan förklara tillväxten av HP-partier eller väljarnas 
sympatier för dem. Om frågor av detta slag ska kunna påverka hur medborgare väljer att rösta måste de politiseras och knytas till politiskt missnöje inom andra samhällsområden, såsom lag och ordning, kriminalitet, familjepolitik, vård och omsorg samt inställning till EU (Kiiskinen \& Saveljeff 20I0; Fryklund 20I5, 20I8). Det gör det än mer intressant att diskutera och analysera hur det politiska etablissemanget bemöter partier som fokuserar på denna typ av politiska sakfrågeområden.

Vi besvarar i denna artikel tre viktiga frågor, som alla tar sin utgångspunkt i ett svenskt sammanhang:

- Hur bemöter de dominerande politiska partierna nya politiska motståndare som delvis förespråkar ett politiskt program som utmanar den liberala demokratins grundvalar?

- Hur kan vi teoretiskt och empiriskt förstå och förklara dessa reaktioner?

- Kan en analys av de strategiska förhållningssätt som används av de dominerande etablerade politiska partierna hjälpa oss att förstå hur HP-partier utvecklas och etablerar sig?

\section{Partiers strategiska bemötande av konkurrenter}

Vi utgår i den här artikeln från hur representanter för det svenska politiska etablissemanget har bemött närvaron av ett HP-parti. Det politiska etablissemanget representeras av de två dominerande och statsbärande partierna, Socialdemokraterna och Moderaterna, eftersom det är de som ställs inför störst utmaningar av Sverigedemokraterna i kampen om väljarna.

Det empiriska materialet utgörs främst av primär data som sammanställts i samband med ett tidigare av forskningsprojekt av Sigrid Saveljeff (20II) samt med Jenny Kiiskinen och Sigrid Saveljeffs doktorsavhandling (20IO). Dessutom har vi använt sekundärt material från perioden 2002-20I8, främst val- och opinionsundersökningar, artiklar, uppsatser, politiska debatter samt officiella politiska uttalanden av Socialdemokraterna och Moderaterna rörande strategiska förhållningssätt till Sverigedemokraterna. 


\section{Positionering, betydelse och ägarskap}

Det teoretiska ramverk som ligger till grund för denna artikel utgår från antagandet att politiska partier är rationella aktörer som strävar mot uppsatta mål. Antagandet är hämtat från rationell partiteori och hävdar att partier väljer de strategier som ger bästa möjliga förutsättningar för att maximera såväl väljarstödet som riksdagsmandaten (Downs 1957; Strom 1990; Håkansson 2005; Meguid 2008; Kiiskinen \& Saveljeff 20IO; Saveljeff 20II).

PSO-teorin (position, salience, ownership), utvecklad av den amerikanska statsvetaren Bonnie Meguid (2005, 2008), gör det möjligt att förstå och, än viktigare, att rekonstruera de strategier de dominerande etablerade politiska partierna använder mot nischpartier. Enligt PSOteorin innefattar de politiska partiernas mål även att maximera den relativa styrkan hos det egna partiet i förhållande till dess huvudmotståndare (Meguid 2008; se även Kiiskinen \& Saveljeff 20IO; Saveljeff 20II). De strategier de etablerade partierna använder för att bemöta utmaningarna från ett HP-parti beror, enligt PSO-teorin, på om partiet anses vara ett hot mot de etablerade partierna eller inte. Hotet bedöms i relation till den politiska sakfråga som läggs fram av HP-partiet och i vilken utsträckning de dominerande partiernas väljarstöd hotas av HP-partiet (Meguid 2008; Kiiskinen \& Saveljeff 20IO; Saveljeff 20II; Fryklund 2018).

Enligt PSO-teorin kan partier som tillhör det politiska etablissemanget välja mellan tre strategier för att bemöta ett nischparti: avvisande, konvergerande och divergerande. De tre strategiernas gemensamma utgångspunkt är den sakfråga som politiserats av nischpartiet. Vad beträffar HP-partier utgörs denna fråga av invandrings- och flyktingfrågan. PSO-teorin fastslår att de dominerande partiernas strategiska respons på ett utmanande HP-parti börjar när de bestämmer sig för om de ska ta ställning i den specifika frågan eller inte (Meguid 2008; Kiiskinen \& Saveljeff 20IO; Saveljeff 20II).

AVVISANDE STRATEGI. Forskning visar att de etablerade politiska partierna använder en avvisande strategi när frågan som politiserats av HPpartiet uppfattas som oviktig eller är alltför svår att bemöta (det vill säga de politiska kostnaderna bedöms bli alltför höga). I sådana fall förhåller 
ARKIV | NR IO | VALET 2OI8

sig de etablerade partierna ofta mer passivt och ignorerar själva frågan såväl som HP-partiet. På så sätt försöker de förmedla till väljarkåren att frågan är oviktig och att en röst på det utmanande partiet är bortkastad eftersom deras politiska program aldrig kommer att förverkligas. Den avvisande strategin lyckas bara om den kan minska HP-partiets väljarstöd tillräckligt för att avvärja hotet från partiet (Meguid 2005, 2008; Kiiskinen \& Saveljeff 20IO; Saveljeff 20II; se även Downs 200I; van Spanje \& van der Brug 2007).

KONVERGERANDE OCH DIVERGERANDE STRATEgIER. Om ett etablerat parti aktivt ska ta ställning i den fråga som politiseras av ett HP-parti står valet mellan två strategier: konvergerande och divergerande. De gör att den fråga som lyfts får större uppmärksamhet, den blir legitim och därför också viktigare för väljarna.

Den konvergerande strategin innebär att det etablerade partiet bemöter hotet från HP-partiet genom att flytta sin ståndpunkt i frågan närmare det utmanande partiets ståndpunkt (Meguid 2005, 2008; Kiiskinen \& Saveljeff 20I0; Saveljeff 20II). Strategin kan ses som ett försök att neutralisera framgången för HP-partiet genom att underminera den särställning som HP-partiet försöker inta i sakfrågan. Väljarna får två partier med likartad inställning i frågan att välja mellan, och enligt PSO-teorin kommer de som initialt tilltalades av det utmanande partiets program men som traditionellt står ideologiskt närmare det etablerade partiet, att överge det förra till förmån för det senare (Meguid 2005, 2008; Kiiskinen \& Saveljeff 20IO; Saveljeff 20II; se även Downs 200I). En konvergerande strategi ger också det etablerade partiet möjlighet att utmana HP-partiet angående ägarskapet till den specifika frågan. Enligt PSO-teorin kommer väljarkåren i detta fall att föredra kopian (det etablerade partiet) framför originalet (HP-partiet) (Meguid 2005, 2008; Kiiskinen \& Saveljeff 20IO; Saveljeff 20II; se även van Donselaar 2003).

Men den konvergerande strategin medför en risk för att väljarstödet för HP-partiet i stället ökar. Uppmärksamheten som riktas mot den fråga de har lyft gör att väljarna tillmäter frågan större betydelse. När det etablerade partiet närmar sig HP-partiets ståndpunkt blir budskapet 
att utmanaren är en legitim politisk aktör, att de inte är paria eller alltför avvikande utan ingår i det politiska etablissemanget och kan betraktas som en tänkbar framtida koalitionspartner (Art 2007; Kiiskinen \& Saveljeff 20IO; Saveljeff 20II).

Den divergerande strategin syftar till att skapa avstånd till HP-partiet och går ut på att det etablerade partiet intar motsatt ståndpunkt i den aktuella frågan (Meguid 2005, 2008; Kiiskinen \& Saveljeff 20I0; Saveljeff 20II; se även Downs 1957; Sjöblom 1968; Capoccia 200I). Även den strategin är förenad med risker: den befäster HP-partiets ägarskap över frågan. Strategin kan också ge HP-partiet möjlighet att locka till sig en större andel av väljarkåren, särskilt bland väljare som inte tidigare röstat på ett HP-parti men som sympatiserar med deras ideologiska hållning $\mathrm{i}$ frågan. Det blir möjligt eftersom inget av de övriga etablerade partierna har en liknande ståndpunkt i frågan (Meguid 2005, 2008; Kiiskinen \& Saveljeff 20IO; Saveljeff 20II).

Det kan verka egendomligt att ett etablerat parti som grundar sina beslut på rationalitet väljer en divergerande strategi för att bemöta en politisk utmanare. Men i flerpartisystem (det svenska politiska systemet såväl som flertalet europeiska politiska system) där ett antal partier kämpar om samma väljare kan ett parti utnyttja en strategi som ökar HPpartiets väljarstöd för att minska väljarstödet för sin huvudmotståndare. Med andra ord: samtidigt som den divergerande strategin förstärker HP-partiet försvagar det huvudmotståndaren, som sannolikt kommer att förlora väljare till HP-partiet. Uttrycket "min fiendes fiende är min vän” stämmer väl in på denna situation (Meguid 2005, 2008; Kiiskinen \& Saveljeff 20I0; Saveljeff 20II).

ASYMMETRISKT OCH SYMMETRISKT HOT. Enligt PSO-teorin avgörs det strategiska förhållningssättet till ett utmanande HP-parti av i vilken omfattning partiet hotar de etablerade partierna, och därtill av hur detta hot fördelar sig mellan dem. Om något av de etablerade partierna upplever att HP-partiet utgör ett större hot än huvudmotståndaren (ett asymmetriskt hot) säger PSO-teorin att partiet kommer att välja en konvergerande strategi. Som en reaktion på detta kommer det andra etablerade partiet att välja en divergerande strategi för att stärka sin makt i förhål- 
ARKIV | NR IO | VALET 2OI8

lande till huvudmotståndaren, som förlorar väljare till det utmanande partiet (Meguid 2008).

Om båda de dominerande partierna hotas i lika mån av HP-partiet (ett symmetriskt hot) är en konvergerande strategi det mest rationella valet enligt PSO-teorin. Då försvagas HP-partiets roll som ägare av den aktuella politiska frågan och väljarna kan i stället komma att rösta på ett etablerat parti.

I fall där inget av de etablerade partierna hotas av det nya partiet är det sannolikt att de kommer att välja en avvisande strategi. Därmed skickar de ett budskap till väljarna att frågan som framförs av HP-partiet saknar betydelse och att en röst på HP-partiet är bortkastad (Meguid 2008; Kiiskinen \& Saveljeff 20I0).

PSO-teorin ger oss möjlighet att förstå hur de etablerade partierna reagerar när de utmanas av ett HP-parti. Det är inte bara deras ståndpunkt i den fråga som har lyfts som påverkas, utan även hur stor betydelse frågan tillmäts och sannolikt väljarkårens syn på vem som äger frågan. Med sin strategi kan de etablerade partierna dramatiskt förändra den politiska arenan. Om de vidtar åtgärder som förändrar frågans betydelse eller HP-partiets ställning som frågans ägare kan det få direkta konsekvenser för HP-partiets väljarstöd (Meguid 2008; Kiiskinen \& Saveljeff 20IO; Saveljeff 20II).

\section{PSO-teorin tillämpad på den svenska kontexten}

Vi menar oss ha sett tecken på att Socialdemokraterna och Moderaterna vid två tillfällen under 2000-talet har bytt inställning till Sverigedemokraterna som konkurrent. För att tydliggöra dessa förändringar och förskjutningar har vi delat in 2000-talet i tre perioder.

\section{Första perioden (2002-2006): avvisande strategi}

Både Socialdemokraterna och Moderaterna använde 2002-2006 den avvisande strategin för att hantera Sverigedemokraternas närvaro (Kiiskinen \& Saveljeff 20I0). Enligt PSO-teorin var det ett rationellt val med tanke på Sverigedemokraternas status som marginellt utkantsparti (jfr Meguid 2005, 2008). Före 2006 års riksdagsval var Sverigedemokraterna 
inget hot mot de två etablerade partierna. De fick inte mer än I,44 procent av rösterna i 2002 års riksdagsval och betraktades som ett marginellt enfrågeparti. Invandrings- och flyktingfrågan rönte ingen större uppmärksamhet från vare sig de etablerade politiska partiernas eller väljarkårens sida.

Men 2006 kan en viss förändring skönjas. I riksdagsvalet detta år fick Sverigedemokraterna 2,93 procent av rösterna. Valresultatet gav inte partiet några platser i riksdagen men däremot nästan 300 kommunfullmäktigeplatser, främst i Sveriges södra delar. Partiet vann också mandat i flera landsting och regioner. Med ens var partiet ett större potentiellt hot mot de etablerade partierna än tidigare. Efter 2006 års val stod det också klart att även om Sverigedemokraterna hade lockat väljare från båda de etablerade partierna, så kom ett avsevärt större antal från Socialdemokraternas väljarkår. Analyser genomförda av Anders Sannerstedt vid Lunds universitet visade att det var Socialdemokraterna som tappade flest röster till Sverigedemokraterna, även om partiet behöll en lojal väljarkår (Sannerstedt 2008; se även Sannerstedt 20IO, 2013, 20I4, 20I5; Kiiskinen \& Saveljeff 20I0). Resultaten från 2006 års val kan ses som en brytpunkt, inte bara vad gäller Sverigedemokraternas valframgång utan också de etablerade partiernas strategier under de följande åren.

\section{Andra perioden (2006-20I0): frän avvisande strategi till konvergerande och divergerande strategier}

Åren efter 2006 års val förändrades de dominerande partiernas strategier gradvis. En rekonstruktion av Socialdemokraternas och Moderaternas förhållningssätt till Sverigedemokraterna visar att invandrings- och flyktingfrågan (den fråga som politiserades av Sverigedemokraterna) blev allt viktigare för utformningen av deras strategier. Det stämmer väl överens med PSO-teorin, enligt vilken som den fråga som ett HPparti lyfter kommer att prägla de etablerade partiernas strategiska val om HP-partiet framstår som ett påtagligt hot mot det politiska etablissemanget.

Vår forskning har visat att båda de dominerande etablerade partierna i Sverige under perioden 2006-20IO övergav sin avvisande strategi och närmade sig strategier som innebar en starkare och i viss utsträckning 
ARKIV | NR IO | VALET 2OI8

förändrad ståndpunkt i invandrings- och flyktingfrågan (Kiiskinen \& Saveljeff 20IO).

Forskning inom detta område tyder dessutom på att Socialdemokraterna under perioden började tillämpa en divergent strategi gentemot Sverigedemokraterna, medan Moderaterna långsamt antog en konvergent strategi.

Värt att notera är att vi i det svenska fallet kan se något som inte direkt kan förklaras av PSO-teorin, nämligen att Socialdemokraterna och Moderaterna kombinerade den sakfrågebaserade strategin med en strategi som innebar att såväl partiet Sverigedemokraterna som dess medlemmar demoniserades och skildrades som extrema, udda, främlingsfientliga och i vissa avseenden till och med rasistiska (Kiiskinen \& Saveljeff 20IO; Hellström 20IO; Saveljeff 20II).

\section{Tredje perioden (20I0-20I8): frän divergens till konvergens med fortsatt demonisering}

I riksdagsvalet i september 2oIo fick Sverigedemokraterna 5,7 procent av rösterna och fick för första gången plats i riksdagen (20 mandat). Det var också första gången sedan början av 1990-talet som ett högerpopulistiskt parti blev representerat i Sveriges riksdag. Valresultatet visade tydligt att Sverigedemokraterna var ett parti att räkna med och att deras politik måste bemötas på riksnivå.

Ur ett forskningsperspektiv underströk valresultatet 2010 behovet av ytterligare teoretiskt förankrad kunskap om de etablerade politiska partiernas strategier. Det var uppenbart att högerpopulistiska partier med representation på riksnivå hade blivit en högst påtaglig verklighet i svensk politik. Efter valet var debatten i stor utsträckning inriktad på hur Sverigedemokraternas närvaro i riksdagen skulle bemötas och vilket slags inflytande partiet kunde förväntas få i politiken (Fryklund 2015). Men det mest intressanta är att debatten inte ledde till någon dramatisk förändring av de två dominerande partiernas strategier. Grunddragen i strategierna kom emellertid med tiden att skärpas.

Utgången av 2014 års val bidrog till ytterligare underlag för vår analys. I detta val fortsatte Sverigedemokraterna att växa och fick fler mandat såväl i riksdagen som i lokala och regionala församlingar. 
Tabell I. Resultat $i$ riksdagsvalen (\% och mandat) under 200o-talet för Sverigedemokraterna, Moderaterna och Socialdemokraterna

\begin{tabular}{|c|c|c|c|c|c|}
\hline & 2002 & 2006 & 2010 & 2014 & 2018 \\
\hline Sverigedemokraterna & $\begin{array}{l}\mathrm{I}, 4 \\
(-)\end{array}$ & $\begin{array}{l}2,9 \\
(-)\end{array}$ & $\begin{array}{r}5,7 \\
(20)\end{array}$ & $\begin{array}{l}\text { I } 2,9 \\
(49)\end{array}$ & $\begin{array}{l}17,5 \\
(62)\end{array}$ \\
\hline Moderaterna & $\begin{array}{l}15,3 \\
(55)\end{array}$ & $\begin{array}{l}26,2 \\
(97)\end{array}$ & $\begin{array}{r}30,1 \\
(107)\end{array}$ & $\begin{array}{l}23,3 \\
(84)\end{array}$ & $\begin{array}{l}\text { I9,8 } \\
\text { (70) }\end{array}$ \\
\hline Socialdemokraterna & $\begin{array}{r}40,0 \\
(\mathrm{I} 44)\end{array}$ & $\begin{array}{r}35,0 \\
(130)\end{array}$ & $\begin{array}{r}30,7 \\
\left(\begin{array}{lll}\text { I } & 2\end{array}\right)\end{array}$ & $\begin{array}{r}3 \mathrm{I}, \mathrm{O} \\
\left(\begin{array}{l}\mathrm{I} \\
\mathrm{I}\end{array}\right)\end{array}$ & $\begin{array}{r}28,3 \\
\text { (100) }\end{array}$ \\
\hline
\end{tabular}

Källa: Val digital

Ända sedan valet 2002 har Sverigedemokraterna tagit röster från framför allt Socialdemokraterna och Moderaterna. Göteborgs universitet presenterade 20I8 nedanstående tabell över väljarövergångar 2006-20I4 från de etablerade partierna till Sverigedemokraterna.

Tabell 2. Antal väljare som Sverigedemokraterna vann frän (+) respektive förlorade till (-) väljargrupper $i$ riksdagsvalen 2006, 2010 och 2014 (tusentals väljare)

\begin{tabular}{lrrr} 
& 2006 & $20 \mathrm{IO}$ & $20 \mathrm{I} 4$ \\
\hline Vänsterpartiet & +5 & +3 & +4 \\
Socialdemokraterna & $+\mathrm{I} 7$ & +27 & +95 \\
Miljöpartiet & $+\mathrm{I} 0$ & +3 & +8 \\
Centerpartiet & $\pm \mathrm{O}$ & $+\mathrm{I} 5$ & +27 \\
Folkpartiet & +2 & +3 & +42 \\
Moderaterna & \pm 0 & $+\mathrm{I} 8$ & $+\mathrm{I} 63$ \\
Kristdemokraterna & \pm 0 & \pm 0 & +27 \\
Feministiskt initiativ & - & $+\mathrm{I} 2$ & \pm 0 \\
Övriga partier & \pm 0 & +3 & -4 \\
Icke-röstare & +5 & $+2 \mathrm{I}$ & +53 \\
Blankröstare & $+\mathrm{I} 7$ & -3 & +8 \\
Förstagångsväljare & $+\mathrm{I} 2$ & +25 & +25 \\
\hline
\end{tabular}

Källa: Valforskningsprogrammets faktablad 20I8:I5 
I valet 2006 var det i första hand Socialdemokraterna som förlorade väljare till Sverigedemokraterna. I 20 Io års val övertog SD ännu fler av Socialdemokraternas väljare och vann dessutom nästan lika många tidigare icke-röstare. Det kan noteras att de första valförlusterna för Moderaterna till SD också kom i 2010 års val, dock bara cirka hälften av vad Socialdemokraterna förlorade. I 2014 års val förlorade sedan Moderaterna avsevärt fler väljare till SD än Socialdemokraterna gjorde.

Efter valet i september 20I4, då Sverigedemokraterna mer än fördubblade sitt väljarstöd jämfört med i 20 o års val, intog de etablerade partierna till en början mer eller mindre samma ståndpunkt som i debatten efter 2010 års val. Sverigedemokraterna ansågs vara ett rasistiskt eller främlingsfientligt parti med icke-demokratiska värderingar. Men jämfört med debatten efter 2010 års val hade något blivit annorlunda. De etablerade partiernas ståndpunkter var inte längre lika strikta som förr. Andra avvikande röster hördes, till och med från ledande politiker (huvudsakligen representanter för de två största partierna), som ansåg att det var dags att normalisera SD och framför allt att normalisera det egna partiets förhållande till SD. Vi menar att det var efter 2014 års val som de första förändringarna i de etablerade partiernas strategier och ståndpunkter i relation till Sverigedemokraterna (Fryklund 2015) kunde skönjas.

Fram till 2014 hade invandrings- och flyktingfrågan ingen större inverkan på hur den svenska väljarkåren röstade (Andersson m.fl. 20I8). Därtill var frågan inte lika politiserad i Sverige som i andra nordiska och europeiska länder, där högerpopulistiska partier fick väljarstöd enbart genom att politisera denna fråga. I analyser som gjordes i samband med riksdagsvalen under perioden 2006-20I4 kunde man urskilja smärre förändringar när det gällde vilken betydelse väljarna tillmätte frågan (Andersson m.fl. 20I8). Under 2014 syntes däremot några tecken på förändring, och i ännu högre grad under senare delen av 2015.

Den djupare politiseringen av invandrings- och flyktingfrågorna hade samband med den relativt stora och accelererande ökningen av invandringen i Sverige under 2015. Enligt Migrationsverkets prognoser i februari 2016 skulle antalet asylsökande under det kommande året öka från 70000 personer till I40 000, och det påverkade med stor säkerhet frågans plats på den politiska dagordningen. Invandrings- och flykting- 
krisen i Europa under 2015 och 2016 ledde till nästintill helt stängda gränser i södra Sverige med identitetskontroller på Öresundsbron mellan Danmark och Sverige. Denna kraftfulla åtgärd av regeringen (och särskilt av Socialdemokraterna, som var regeringens dominerande parti) fick omedelbara konsekvenser för de andra nordiska ländernas invandringspolitik: framför allt Danmark men även Norge och Finland påverkades starkt. Det är sannolikt att politiseringen av invandrings- och flyktingfrågan kommer att fortsätta och förmodligen också intensifieras under kommande år.

När den här artikeln färdigställs har riksdagsvalet 2018 ägt rum. Den stora vinnaren sedan förra valet är Sverigedemokraterna, som ökade med 4,6 procentenheter (I3 mandat). Förlorarna är framför allt Socialdemokraterna (minskning med 3,49 procentenheter till 28,3 procent) och Moderaterna (minskning med 2,75 procentenheter till 19,8 procent). Socialdemokraterna tappade I4 riksdagsmandat och Moderaterna I3. Valresultatet 2018 innebar vidare att Sverigedemokraterna med sina 62 mandat har en potentiell vågmästarroll mellan vänsterblocket $(S, V$ och $M P)$ och högerblocket (M, CP, L och KD). Inget av blocken fick en klar majoritet i riksdagen, vilket komplicerade regeringsbildningen.

Sverigedemokraterna har haft en uppåtgående trend sedan millennieskiftet med allt större väljarstöd i val efter val. De fortsatte i detta val att plocka röster från Moderaterna och Socialdemokraterna. Vi kan också konstatera att invandrings- och flyktingfrågan har befunnit sig högt upp på den politiska agendan. Inför riksdagsvalet 20I8, då Sverigedemokraterna enligt prognoser förväntades växa kraftigt och både Moderaterna och Socialdemokraterna antagit mer konvergerande strategier, var det en inte alltför djärv prognos att båda partierna skulle tappa väljare till SD.

Då denna artikel skrevs var valanalyserna ännu inte helt färdigställda, men såväl $S$ som $M$ tappade även denna gång ett stort antal väljare till SD. SVT:s vallokalsundersökning visade att ungefär lika stora andelar väljare från $S$ och $\mathrm{M}-5$ respektive 4 procentenheter - gick över till SD och mindre från de andra partierna. Det är ett rimligt påstående att förändringarna i den svenska invandringspolitiken på senare år har påverkat de dominerande etablerade partiernas strategier gentemot Sverigedemokraterna och att det i sin tur har påverkat väljarflödet mellan partierna. 
Ett intressant resultat, som också framkom i SVT:s vallokalsundersökningar, är att Sverigedemokraterna har den mest stabila väljarbasen: av dem som röstade på SD 2014 gjorde hela 86 procent det även 2018. Traditionellt har Socialdemokraterna haft mest stabil väljarbas (69 procent). Om detta sakförhållande består kommer $\mathrm{S}$ och $\mathrm{M}$ sannolikt att ha betydande svårigheter att vinna tillbaka de väljare som gått över till SD. En effekt av det kan bli att de etablerade partierna, som Socialdemokraterna, koncentrerar sig på att behålla de väljare som av lojalitetsskäl fortsatt röstar på S men som sympatiserar med SD:s migrationspolitik, och inte på att försöka vinna tillbaka dem som lämnat $S$ för SD. Det kan leda till att $S$ måste förstärka sin konvergerande strategi gentemot $\mathrm{SD}$ och tona ned den divergerande inriktningen. En sådan strategi för att behålla lojala väljare som sympatiserar med SD:s migrationspolitik kan å sin sida medföra påfrestningar på sammanhållningen bland partiets medlemmar.

För Moderaternas vidkommande är den politiska situationen något annorlunda. De behöver inte förändra sin i huvudsak konvergerande strategi med anledning av valet. Dock kan de komma att förstärka strategin något i syfte att behålla sin väljarbas. Moderaterna har ett annat och kanske till och med större bekymmer än att hantera migrationsfrågan strategiskt gentemot SD: Sverigedemokraterna strävar programmatiskt mot att bli ett konkurrerande socialkonservativt parti. De skulle i så fall konkurrera med Moderaterna om de socialkonservativa väljare som förutom en stram och reglerad migrationspolitik efterfrågar lag och ordning, ett starkt försvar, ett nationalistiskt präglat värdesystem, selektiv socialpolitik (riktad till dem som har det allra sämst ställt, i motsats till en generell socialpolitik).

\section{Trovärdighet, rationalitet och det demokratiska dilemmat}

PSO-teorin med tillhörande modell ger en god förståelse av hur olika faktorer påverkar de dominerande etablerade partiernas strategiska förhållningssätt gentemot ett utmanande HP-parti. Intressant nog tycks de strategier som Socialdemokraterna och Moderaterna använder gentemot 
Sverigedemokraterna inte över tid följa den idealmodell som stipuleras av PSO-teorin. Det är alltså nödvändigt att jämföra den konkreta verkligheten med idealmodellen och diskutera hur de skiljer sig åt.

Enligt PSO-teorin bör det etablerade parti som är mest hotat av ett utmanande HP-parti röra sig mot ett konvergerande förhållningssätt i syfte att få tillbaka sina väljare. Det etablerade parti som inte är lika hotat bör i stället stärka sin position gentemot det andra etablerade partiet genom att välja en divergerande strategi. Men i det svenska fallet har vi sett motsatsen. Socialdemokraterna är det parti som hotas mest av Sverigedemokraterna, men de tillämpade i början inte en konvergerande strategi (som modellen stipulerar) utan snarare en divergerande, med uttalanden som markerade avståndstagande (Kiiskinen \& Saveljeff 20I0). I en debattartikel i Aftonbladet 19 januari 2008 skrev Marita Ulvskog: "För oss är alla människor lika mycket värda och har samma rätt. För Sverigedemokraterna är det skillnad på människors värde beroende på var de kommer ifrån, vad de tror på och vilken hudfärg de har. En avgrund skiljer deras värderingar från de värden som vi menar bygger ett gott samhälle.” Moderaterna har däremot under samma period intagit en ganska reserverad ståndpunkt i kombination med vaga tendenser till konvergens (jfr Kiiskinen \& Saveljeff 20IO).

Vi menar att faktorn trovärdighet är väsentlig för att förstå de etablerade partiernas strategier. Forskning av till exempel Meguid (2008) och Kiiskinen och Saveljeff (20IO) har visat att trovärdighet är viktigt bland annat för att bevara sammanhållningen inom partiet. För att bevara partisammanhållningen i invandrings- och flyktingfrågan under den andra perioden och delvis den tredje perioden såg sig Socialdemokraterna tvungna att tillämpa en divergerande strategi gentemot Sverigedemokraterna. Historiskt har Socialdemokraternas ideologiska ståndpunkt i invandrings- och flyktingfrågan legat en bra bit från Sverigedemokraternas, och om Socialdemokraterna skulle tillämpa en konvergerande strategi och närma sig Sverigedemokraterna skulle det förmodligen skada deras trovärdighet hos partimedlemmarna. Ur den synvinkeln är Socialdemokraternas strategier - divergerande under den andra perioden och svagare divergerande med tendenser till konvergerande under den tredje perioden - begripliga. 
I Socialdemokraternas fall kan en konvergerande strategi tilltala väljare som lämnade partiet till förmån för Sverigedemokraterna vid valen 2006 och 20ı, men också väljare som sympatiserar med Sverigedemokraternas invandrings- och flyktingpolitik men av lojalitet röstar på Socialdemokraterna. ${ }^{I}$ De första tecknen på konvergerande drag hos Socialdemokraterna dök upp efter flyktingkrisen 2015/2016. Socialdemokraterna skärpte under denna period sin politiska retorik i invandringsfrågan, och införandet av ID-kontroller vid Sveriges gräns i söder satte igång en debatt inom partiet angående ideologiska parametrar och den socialdemokratiska värdegrunden. På en presskonferens den 4 maj 2018 presenterade partiledningen sin nya skärpta migrationspolitik. Statsminister Stefan Löfven och migrationsminister Heléne Fritzon lade fram ett program med fokus på vad som kallades En trygg migrationspolitik för en ny tid (Socialdemokraterna 2018). Programmet omfattade kraftfulla skärpningar på en rad områden: mottagandets omfattning och utformning och vad som skulle ske när någon nekades att stanna i Sverige. Stefan Löfven framhöll dessutom på presskonferensen vikten av att den som får avslag på sin ansökan lämnar landet. Det skall även gälla barn som därmed inte får gå kvar i skolan, menade statsministern (Aftonbladet 4 maj 20I8): "Har man fått nej och inte har tillåtelse att vara i landet kan man inte få ta del av svensk välfärd på samma sätt som människor som ska vara här."

Hård kritik från ledande företrädare för partiet lät inte vänta på sig. Först kom stark kritik från socialdemokratiska kommunalråd och partiets sidoorganisationer, som menade att partiets nya linje bland annat skulle medföra ytterligare svårigheter för familjer att återförenas och därigenom ytterligare integrationsproblematik (Aftonbladet 17 maj 20I8). Därefter följde kritik från ett antal S-veteraner. En av dem var den förre finansministern Erik Åsbrink, som dessutom menade att S-tappet i opinionen kunde tolkas som att strategin att vinna tillbaka de väljare som gått till SD hade misslyckats trots att $\mathrm{S}$ nyligen presenterat en skärpt

I. Här är det intressant att jämföra med motsvarande utveckling i Danmark: Där har ett politiskt klimat utvecklats där de danska Socialdemokraterna konvergerat mot Dansk Folkepartis ståndpunkt i invandrings- och flyktingfrågor och till och med föreslagit en koalitionsregering med Dansk Folkeparti. 
migrationspolitik. "SD kan säga att 'vi är originalet och de andra är bleka kopior som man kan lita på’, sa Åsbrink (Aftonbladet 24 maj 20I8). Även den förra socialdemokratiska vice statsministern Margareta Winberg uttryckte sin oro över partiets förändrade hållning (Aftonbladet 24 maj 20I8): ”Jag har varit i väldigt många valrörelser och det har aldrig låtit så här.” Margareta Winberg var också uttalat kritisk mot partiledningen (Aftonbladet 24 maj 20I8): "Att utspelen om hårdare tag och migrationen dominerar debatten och prioriteras av väljarna är ingen ursäkt." Lena Hjelm-Wallén, tidigare utbildnings- och utrikesminister, beskrev partiets retorik som onödigt hård (Aftonbladet 24 maj 20I8): "Det är självklart att vi inte kan vara så mycket mer öppna än EU. Men idag, då det inte är någon större flyktingström, behöver man inte hålla fram att vi ska ligga på EU:s lägsta nivå.”

Uttalandena från partiledningen och det presenterade partiprogrammet antyder att partiet framöver kan röra sig i riktning mot en mer konvergerande strategi. De kritiska uttalandena från partimedlemmarna visar dock att dessa hellre hade sett en divergerande strategi i förhållande till Sverigedemokraterna. I uttalandena från partiledningen och partimedlemmarnas kritik framträder, menar vi, den dubbla strategi som Socialdemokraterna försöker använda sig av för att hantera den splittring som finns inom partiet vad gäller migrationspolitiken.

Moderaterna är det etablerade parti som historiskt har varit mest negativt inställt till en generös invandrings- och flyktingpolitik. Undantaget var regeringsperioden 20IO-20I4, när Moderaterna genom sin partiledare statsminister Fredrik Reinfeldt föreslog en mer generös och liberal invandringspolitik. De tendenser till konvergens som skymtade i partiets förhållningssätt till Sverigedemokraterna under den andra perioden stred inte mot partimedlemmarnas åsikter och med stor sannolikhet inte heller mot majoriteten av deras väljares, och hotade därför inte partiets trovärdighet hos partimedlemmarna och väljarna (se även Kiiskinen \& Saveljeff 20IO).

På senare år, när väljarstödet för SD har ökat, har Moderaterna hållit fast vid sin strategi men förstärkt en del av retoriken kring invandringsfrågan, vilket syns i partiets partiprogram (Moderaterna.se, Integration). Under de senaste åren tycker vi oss också ha sett flera tecken på konver- 
gerande drag i Moderaternas strategi, bland annat i svängningarna i retoriken om kostnader för invandringen. Sverigedemokraterna har under lång tid propagerat för att invandringens kostnader ska tydliggöras (och jämföras med andra politiska budgetposter för omfördelning). Moderaternas ståndpunkt har varit den motsatta. Dock har den förändrats något, vilket kan illustreras med det uttalande som Moderaternas ekonomisk-politiska taleskvinna Elisabeth Svantesson gjorde i en intervju med Dagens Nyheter i februari 20I8: hon hävdade att det funnits "en tendens att inte prata om invandringens kostnader" och argumenterade för att dessa kostnader skulle redovisas tydligare. Att Moderaterna rör sig i riktining mot en konvergerande strategi gentemot Sverigedemokraterna kan inte anses utmana Moderaternas trovärdighet hos den egna väljarkåren (jfr Kiiskinen \& Saveljeff 20Io). Opinionsundersökningar under de senaste åren, särskilt sedan hösten 2017 då Ulf Kristersson tillträdde som partiledare, bekräftar att strategin med inslag av konvergens varit delvis framgångsrik. Partiet har i någon utsträckning lyckas ta tillbaka väljare från Sverigedemokraterna (Sifo-undersökning 20I7; Andersson m.fl. 20I8), även om det inte fick reellt genomslag i riksdagsvalet 2018.

En annan faktor som är viktig att beakta är Sverigedemokraternas "antietablissemangsstrategi". Historiskt har SD framställt sig som ett parti utanför det politiska etablissemanget med en ståndpunkt i invandrings- och flyktingfrågan som var starkt påverkad av "folkets" åsikter. Varken Socialdemokraterna eller Moderaterna kunde därför under de två första perioderna använda en konvergerande strategi - att de är en del av etablissemanget gör det svårt, men inte omöjligt, för dem att lägga sig nära HP-partiets ståndpunkt. Samtidigt bör sägas att Sverigedemokraterna har försökt bli en del av det politiska etablissemanget - mest intensivt under den tredje perioden i kraft av partiets ökande storlek eller åtminstone erkännas som en legitim del av riksdagens arbete och det allmänna politiska systemet.

En tydlig förflyttning mot en konvergerande strategi skulle för Socialdemokraterna troligen sätta partiets trovärdighet på spel, men för Moderaterna skulle det kunna få motsatt effekt. 


\section{Bilden av Sverigedemokraterna}

Det återstår ett perspektiv som inte kan förklaras av PSO-teorin. I Sverige har uppfattningen om Sverigedemokraterna visat sig vara en viktig faktor som har potential att påverka innehållet i de dominerande etablerade partiernas strategiska förhållningssätt (se även Kiiskinen \& Saveljeff 20IO; Saveljeff 20II). Sverigedemokraterna har omgetts av en mycket negativ uppfattning som fătt en nästan hegemonisk status i det svenska politiska landskapet. Den negativa bilden av Sverigedemokraterna har ofta ställts mot idealbilden av den liberala demokratins principer, såsom pluralism, tolerans och respekt för etniska minoriteter (jämför det demokratiska dilemmat).

De negativa uppfattningarna om Sverigedemokraterna har begränsat vilka strategiska val som är tillgängliga för de etablerade partierna. Det kan hjälpa oss att förstå varför Socialdemokraterna och Moderaterna har tvekat att använda en konvergerande strategi. Inte förrän under de senaste åren, efter invandrings- och flyktingkrisen 2015/20I6 då det politiska klimatet förändrades i invandringsfrågan i Sverige såväl som i resten av Europa, har en mer uttalad konvergerande strategi blivit ett möjligt val för de dominerande etablerade partierna. Eftersom Sverigedemokraternas ståndpunkt i invandrings- och flyktingfrågan historiskt har framställts som alltför extrem, främlingsfientlig, rasistisk och odemokratisk, har inget av de båda etablerade partierna velat inta en ståndpunkt i frågan som närmar sig Sverigedemokraternas. Den negativa uppfattningen om Sverigedemokraterna (och deras syn på invandrings- och flyktingfrågan) har inskränkt eller åtminstone fördröjt de strategiska val som stått till buds för de etablerade partierna. Vår forskning visar således att trovärdighet fortfarande är en avgörande faktor i de etablerade partiernas val av strategiska förhållningssätt. Trovärdighetsfaktorn är viktig av flera anledningar, bland annat för att bibehålla sammanhållningen inom partiet.

\section{Rationellt eller inte?}

Kan de strategiska val Socialdemokraterna och Moderaterna gjort under de senaste åren anses vara rationella? Vårt svar på den frågan är ett preliminärt ja. Även om de etablerade partiernas strategiska förhållningssätt 
inte sammanfaller med det idealtypiska förhållningssätt som stipuleras av PSO-teorin kan vi likväl betrakta Socialdemokraternas och Moderaternas val som rationella. Båda partierna har valt en strategi som gett dem gynnsammast möjliga ståndpunkter vid de allmänna valen under 2000-talet. Att minska Sverigedemokraternas väljarstöd har inte varit det enda större målet för de båda partierna, utan partiernas trovärdighet gentemot partimedlemmarna i första hand och väljarkåren $i$ andra hand har haft högre prioritet till följd av en dominerande normativ hållning $\mathrm{i}$ Sverige som framhäver betydelsen av mänskliga rättigheter, tolerans och respekt för allas lika värde oavsett etnicitet.

\section{Närvaron av högerpopulism: ett demokratiskt eller strategiskt dilemma?}

Med tanke på utvecklingen under de senaste åren, är det fortfarande möjligt att dra slutsatsen att närvaron av HP-parti är ett demokratiskt dilemma för det politiska etablissemanget? Ja, men i olika utsträckning. Dilemmat kommer till uttryck i att innehållet i det strategiska förhållningssättet gentemot Sverigedemokraterna måste konstrueras kring en fråga (invandrings- och flyktingfrågan) som är tätt sammanflätad med mänskliga värden och principer som pluralism och tolerans.

Socialdemokraterna liksom Moderaterna signalerar att det strategiska förhållningssättet gentemot Sverigedemokraterna behöver formas och formuleras på ett sätt som ger de etablerade partierna möjlighet att hantera det demokratiska dilemmat. Därför ger det demokratiska dilemmat upphov till ett strategiskt dilemma. De etablerade partierna måste pröva de mål de eftersträvar mot HP-partiets närvaro på den politiska scenen (och dess konsekvenser), samtidigt som de förhåller sig till den starkt värdeladdade fråga som politiserats av HP-partiet och det demokratiska dilemma som närvaron av HP-partiet ger upphov till. Därför förändras det demokratiska dilemmat, och målet att inte förlora fler röster har blivit övergripande. Det resulterar i att det demokratiska dilemmat blir underordnat det strategiska dilemmat. Det understryker också behovet av ytterligare utveckling av den modell som kopplas till PSO-teorin. 


\section{Vad händer nu? Den fortsatta utvecklingen}

PSO-teorin (position, salience, ownership) (Meguid 2005, 2008) med tillhörande modell var utgångspunkten för vår analys av de etablerade partiernas strategiska förhållningssätt gentemot högerpopulistiska partier. Enligt PSO-teorin kan partier som tillhör det politiska etablissemanget välja mellan tre strategier för att bemöta ett nischparti: den avvisande, den konvergerande och den divergerande. Oavsett strategi måste de etablerade partierna förhålla sig till den sakfråga som framförs av nischpartiet, vilken för HP-partier ofta utgörs av invandrings- och flyktingfrågan. Vi har tillämpat den modell som grundar sig på PSO-teorin på samhällsutvecklingen i Sverige under 2000-talet, och också gjort en mindre utblick över Europa och Norden för att vidga perspektivet.

Det finns förbehåll som är relevanta för att förstå denna modells tillämpbarhet i svensk kontext. Först och främst har de flesta länder i Europa, däribland Sverige, flerpartisystem, inte tvåpartisystem som USA och Storbritannien. PSO-teorin är starkt påverkad av situationen med två partier som utmanas av ett nischparti. För det andra är ett högerpopulistiskt parti inte ett typiskt nischparti utan har i de flesta fall relativt starkt stöd hos väljarkåren, vilket kan ha betydelse för vilka politiska strategier det politiska etablissemanget tillgriper. Därför är det viktigt att förstå vad populism och populistiska partier är.

Med vår tidigare forskning och vår analys i denna artikel som underlag kan vi visa hur, varför och ungefär när de etablerade partierna förändrade sina politiska strategier gentemot Sverigedemokraterna. Vi delade in de senaste åren i tre perioder, med början 2002 när Sverigedemokraterna på allvar gjorde sitt intåg på den politiska arenan. På så sätt kan vi följa hur de politiska strategierna har förändrats och hur Sverigedemokraterna växt och förändrats i takt med att invandrings- och flyktingfrågan har blivit en alltmer central politisk samhällsfråga som inverkar på flera andra viktiga politikområden. Det är dock viktigt att understryka att det i den samhälleliga verkligheten handlar om processer (långsamma eller snabba) med avbrott (sprickor) som inte låter sig fångas i en enkel tabell.

Vi kunde urskilja en utveckling från starkt avvisande strategier under den första perioden (2002-2006) hos båda de dominerande partierna, 
ARKIV | NR IO | VALET 2OI8

till en divergerande strategi hos Socialdemokraterna och vaga tendenser till konvergens hos Moderaterna under den andra perioden (2006-20I0) och vidare mot en relativt tydlig konvergerande strategi hos Moderaterna samt en blandning av konvergens och divergens hos Socialdemokraterna under den tredje perioden (20IO-20I8).

Under den första perioden (2002-2006) utgjorde Sverigedemokraterna inget hot mot de etablerade partierna, och dessas val av en avvisande strategi var självklart och rationellt. Under den andra perioden (2006-2010) började det politiska landskapet och samhällskontexten att förändras. Som mest intensivt var det för Socialdemokraterna, som försvagades genom att de var det av de dominerande partierna som förlorade flest röster till Sverigedemokraterna i valen 2006 och 20Io. I valet 2006 kom Sverigedemokraternas röster nästan uteslutande från Socialdemokraterna (och icke-röstande). I valet 20 Io förlorade även Moderaterna röster, men inte i samma utsträckning som Socialdemokraterna. Vår slutsats är att Socialdemokraterna använde den divergerande strategin för att minska väljarstödet för huvudmotståndaren Moderaterna, som befann sig på motsatt sida av det politiska spektrumet. Moderaterna å sin sida valde en provisorisk konvergerande strategi och försökte konkurrera med Sverigedemokraterna om de röster som kunde tänka sig att röra sig mellan de båda partierna.

Under den tredje perioden (20IO-20I8) förändrades det politiska läget. Moderaterna blev det mest hotade av de etablerade partierna och förlorade flest röster till Sverigedemokraterna i 2014 års val. Enligt SCB:s omfattande analys av 20I4 års val kom ungefär 26 procent av Sverigedemokraternas väljare från Moderaterna, vilket motsvarar en röstförlust på ungefär 8 procent. Motsvarande andel för Socialdemokraterna var hälften, 4 procent. Att Moderaterna valde en konvergerande strategi gentemot Sverigedemokraterna bör alltså inte förvåna. Under den tredje perioden och fram till nu (20I8), har Moderaterna tagit upp kampen om väljarna med Sverigedemokraterna med hjälp av en starkt konvergerande strategi. Det politiska läget, i kombination med det politiska klimat som uppstod efter migrationskrisen 2015/2016, har medfört en efterfrågan på en mer restriktiv invandrings- och flyktingpolitik i Sverige och hela Europa. Det har satt press på Socialdemokraterna att använda 
Tabell 3. Socialdemokraternas (S) och Moderaternas (M)

strategier gentemot Sverigedemokraterna 2002-2018

\begin{tabular}{|c|c|c|c|c|}
\hline & & \multicolumn{3}{|c|}{ STRATEGI } \\
\hline : & $S$ & Starkt avvisande & & \\
\hline 9 & M & Starkt avvisande & & \\
\hline$\stackrel{0}{0}$ & $S$ & & Starkt divergerande & \\
\hline : & M & & & $\begin{array}{l}\text { Tendenser till } \\
\text { konvergens }\end{array}$ \\
\hline $\begin{array}{l}\infty \\
\text { ర్స }\end{array}$ & S & & $\begin{array}{l}\text { Svagare divergerande } \\
\text { än 2006-20IO }\end{array}$ & $\begin{array}{l}\text { Vissa tendenser till } \\
\text { konvergens }\end{array}$ \\
\hline סֶ: & M & & & $\begin{array}{l}\text { Starka tendenser till } \\
\text { konvergens }\end{array}$ \\
\hline
\end{tabular}

en mer konvergerande strategi när de deltar i kampen om väljarna, men partiet försöker fortfarande hålla fast vid den (svagare) divergerande strategin. Den strategi som Socialdemokraterna för närvarande använder sig av kallar vi en blandad eller dubbel konvergens- och divergensstrategi.

Vi har i Sverige bevittnat en rörelse från avvisande till konvergerande strategier för båda de etablerade partierna, med en divergerande mellanperiod för Socialdemokraterna. En tänkbar förklaring till förändringen mot konvergens kan vara att det demokratiska dilemmat har blivit alltmer underordnat det strategiska dilemmat: båda partierna prioriterar att få fler röster, antingen genom att vinna tillbaka röster som förlorats till Sverigedemokraterna vid tidigare val eller genom att förebygga risken att förlora fler röster i kommande val.

Vi har problematiserat PSO-teorin med tillhörande modell genom att tillämpa den på den sociala och politiska utvecklingen i Sverige på 2000-talet, med beaktande av faktorer såsom trovärdighet, rationalitet och demokratisk legitimitet tillsammans med i vilken grad det föreligger ett demokratiskt och strategiskt dilemma. Vår bedömning är att dessa 
faktorer är unika för den svenska kontexten och att de påverkat vilka strategier som står till buds för de etablerade partierna och vilka de väljer. Vi menar att framhävandet av dessa faktorer inte strider mot PSO-teorin och dess modell, utan snarare belyser behovet av fortsatt utveckling av denna modell.

\section{Efter riksdagsvalet 2018 - förändring av de politiska strategierna inför den närmaste framtiden?}

När denna artikel färdigställs har det svenska riksdagsvalet 2018 relativt nyligen ägt rum. Ett val som påvisade en utökad väljarbas för Sverigedemokraterna och ledde till en svårhanterlig parlamentarisk situation. Fram till valdagen i september 2018 visade Socialdemokraterna såväl som Moderaterna konvergerande tendenser och rörde sig närmare Sverigedemokraternas ståndpunkt i invandringsfrågor. Vår analys är att rörelsen berodde på opinionsmätningar som visat stora väljarförluster för de etablerade partierna till Sverigedemokraterna under det senaste året, vilket valresultatet befäste. Behovet av att minska förlusterna har tvingat de etablerade partierna att överge sina tidigare strategier till förmån för en mer konvergerande strategi.

Hur ser väljarprofilen ut för SD jämfört med för de två huvudkonkurrenterna $S$ och $M$ ? Det är av stor betydelse för vilken politisk strategi som Socialdemokraterna respektive Moderaterna framgent kommer att använda. För att börja närma oss svaret på frågan bör vi titta på partivalet i riksdagsvalet utifrån yrke och fack, det vill säga det som närmast motsvarar och används som ett mått på samhällsklasser och deras organisering.

SD:s väljarprofil liknar Socialdemokraternas vad avser andelen arbetarväljare och LO-medlemmar, arbetslösa och sjuka med aktivitetsersättning. Vi kan dock se att de skiljer sig åt när det gäller stöd från tjänstemän och TCO- och Sacomedlemmar, där SD har betydligt svagare stöd än S. Däremot har SD nästan dubbelt så starkt stöd hos företagare som $S$ och liknar där mer $M$, vilket i sig är intressant. Sammanfattningsvis har SD har starkt väljarstöd bland arbetare, arbetslösa, sjukskrivna och företagare. Deras väljarprofil liknar till viss del Moderaternas vad gäller andelen företagare och jordbrukare, men skiljer sig åt när det gäller stödet 
Tabell 4. Röstning i riksdagsvalet 2018 efter yrke och fack (\%)

\begin{tabular}{lrrrrrrrrrr} 
Yrke och fack & V & S & MP & C & L & KD & M & SD & FI & Övr \\
\hline Förvärvsarbetande & 8 & 25 & 5 & 9 & 6 & 6 & 2 I & I7 & I & 0 \\
Arbetslösa & 8 & 3 I & 2 & 7 & 4 & 5 & I7 & 24 & I & I \\
Sjuk-/aktivitetsersättn. & I I & 36 & 3 & 3 & 5 & 4 & 7 & 30 & I & 0 \\
Studerande & I4 & 26 & 8 & I I & 4 & 5 & 2 I & 8 & 2 & I \\
Arbetare & 9 & 34 & 3 & 6 & 3 & 6 & I4 & 24 & I & I \\
Tjänstemän & 7 & 27 & 5 & I0 & 7 & 7 & 22 & I 2 & I & 0 \\
Jordbrukare & 2 & 22 & 0 & 39 & 0 & 5 & I4 & I6 & 0 & I \\
Företagare & 5 & I 3 & 3 & I0 & 5 & 8 & 30 & 24 & I & I \\
LO & 9 & 4 I & 2 & 5 & 2 & 4 & I I & 24 & I & 0 \\
TCO & 9 & 32 & 5 & 8 & 6 & 7 & I 8 & I 3 & 2 & 0 \\
Saco & IO & 25 & 8 & I2 & 9 & 6 & I7 & 9 & 2 & 0 \\
\hline
\end{tabular}

Källa: SVT Valu 20I8, s. I7

\section{Tabell s. Sverigedemokraternas väljarprofil 2018}

\begin{tabular}{lc} 
Grupp & Röstade på SD (\%) \\
\hline Samtliga & 23 \\
Män & 24 \\
LO-medlemmar & 24 \\
Arbetslösa & 32 \\
Anser att det vore bra ta emot färre flyktingar & 36 \\
Ser flyktingar/invandring som mycket viktig fråga & 23 \\
Högerideologi & 33 \\
Lågt politikerförtroende & 23 \\
\hline
\end{tabular}

Källa: SVT Valu 20I8, s. $4 I$ 
från arbetare och tjänstemän, där SD har starkare stöd bland arbetare och mindre bland tjänstemän jämfört med $\mathrm{M}$. Hos studerande plus akademiker i Saco är väljarstödet för SD mycket svagare än för S och M. Väljarprofilerna för $\mathrm{M}, \mathrm{S}$ och SD kommer med stor sannolikhet att inför den närmaste framtiden påverka hur $\mathrm{M}$ och $S$ förhåller sig till $S D$, i vad vi kan kalla ett triangulärt komplicerat relationsmönster.

Valu 2018 presenterar också en kompletterande tabell som ger en social profil av vilka som röstade på SD samt vilka frågor och uppfattningar som var viktiga för dem som röstade på SD i valet 2018.

En typisk SD-väljare är alltså en man som är arbetare eller arbetslös från LO-facket, som har lågt förtroende för politiker, har en konservativ värdegrund och anser att flykting- och invandringsfrågan är mycket viktig med innebörden att Sverige ska ta emot färre flyktingar. Till denna bild kan läggas att han har låg utbildning och inkomst, till och med lägst av alla partiers väljare (SVT Valu 20I8).

Utifrån denna väljarprofil är det intressant att reflektera kring en debattartikel som publicerades i Dagens Nyheter hösten 20I8: "Arbetslinjen och finanskris förklarar SD:s framgångar" (Dagens Nyheter 5 september 20I8). I artikeln resonerar forskarna Olle Folke, Torsten Persson och Johanna Rickne kring att Sverigedemokraternas framgångar synes sammanfalla med två ekonomiska skeenden och arbetsmarknadspolitiska åtgärder som givit stora väljargrupper sämre ekonomiska och sociala villkor, särskilt i relativa termer: dels den så kallade arbetslinjen som infördes av den borgerliga regeringen under 2006, dels den lågkonjunktur som eskalerade under 2008. Forskarna menar att följden blivit att de väljare som fått sämre ekonomiska villkor alltmer förlorat sin tillit till det politiska etablissemanget. Dessa väljare har därför sökt sig till SD, som byggt stora delar av sin politik på kritik av det politiska etablissemanget.

Vidare menar forskarna i debattartikeln att de som fått det sämre ställt tenderar att starkare identifiera sig med den egna gruppen och lägga skulden på andra, till exempel det politiska etablissemanget och invandrare/flyktingar. Det innebär att ett parti som utlovar omfördelning av de statliga medlen från utlandsfödda till Sverigefödda, och samtidigt kritiserar det politiska etablissemanget, tenderar att bli mer attraktivt för dessa grupper. 
Forskarna fann överraskande nog inget direkt samband mellan SD:s framgångar och den ökade invandringen. Vår kommentar är att det inte är antalet invandrare i kommunen eller valdistriktet som är det avgörande kriteriet i sammanhanget, utan föreställningen om vad ökad invandring kan komma att föra med sig. Vi finner dock forskningsresultaten intressanta och menar att dessa studier förstärker den bild vi har förmedlat $\mathrm{i}$ den här artikeln. I denna liksom i tidigare artiklar (Fryklund 20I5, 20I8) och forskningsstudier (Kiiskinen \& Saveljeff 20IO; Saveljeff 20II) har vi påvisat att SD:s framgångar bygger på att partiet lyckats fånga upp ett politiskt och socialt missnöje, med sin grund hos samhällsutvecklingens ekonomiska förlorare, och kanaliserat det via invandrings- och flyktingfrågan. Med andra ord är invandrar- och flyktingfrågan den organiserande principen för högerpopulismens ställningstaganden på andra politikområden, som etnisk nationalism, kriminalitet och lag och ordning. Det är också den frågan som politiskt mobiliserar SD:s väljare, grundat i ett socialt och ekonomiskt missnöje. Det gäller särskilt tidigare socialdemokratiska väljare och tidigare icke-röstare, inte alls i samma utsträckning tidigare moderata väljare, som kan räknas in i gruppen socialkonservativa med politiska högeråsikter.

Den samlade bilden av SD:s valframgångar överensstämmer också med Cas Muddes analys som vi presenterade ovan, där han framhåller att några av de mest framträdande egenskaperna hos högerpopulistisk ideologi är socialkonservatism, auktoritetstro och nationalism - ideologier och åsikter som finns hos majoriteten av väljarkåren. Faktum är att Mudde uppfattar dessa som en "radikalisering av normala värderingar. Därför bör den populistiska högern betraktas som patologisk normalitet och inte som normal patologi” (Mudde 20IO, s. II8I).

I en artikel nyligen i European Journal of Political Research drar författarna Paul Marx och Christoph Nguyen (2018) liknande slutsatser. Framgångarna för vad Marx och Nguyen kategoriserar som "anti-elitpartier" bygger på att de mobiliserar väljare från de lägre samhällsskikten, vilket medför att dessa grupper ökar sitt deltagande i de politiska processerna. Därigenom bidrar närvaron av sådana partier paradoxalt nog till att förstärka det demokratiska valdeltagandet i politiken (Marx \& Nguyen 20I8). 
Vad resultatet av riksdagsvalet 2018 leder till för regering de närmaste fyra åren vet vi i skrivande stund inte. Vad vi däremot vet är att Sverigedemokraterna kommit att inta rollen som vågmästare i riksdagen, mitt emellan de traditionella blocken. Det innebär att Sverigedemokraterna har fått en nyckelroll i hur politiska majoriteter formas i den nya riksdagen och kanske också i hur de kommer att formas längre framöver. Valet 2018 öppnade upp för en helt ny politisk situation i Sverige. Frågan vilka strategier de två statsbärande och största partierna Socialdemokraterna och Moderaterna kommer att använda gentemot det högerpopulistiska partiet Sverigedemokraterna är central för hur det politiska landskapet kommer att gestalta sig den närmaste framtiden.

Det rådande politiska klimatet i Sverige gör att vi kan konstatera att det demokratiska dilemmat har blivit underordnat det strategiska dilemmat. Värt att poängtera är dock att underordningen inte innebär att det demokratiska dilemmat nu saknar betydelse för de strategiska val som de etablerade partierna gör i bemötandet av de högerpopulistiska partierna. Dilemmat är ständigt närvarande, om än i något förändrad form, och är något de etablerade partierna aldrig kan bortse från.

\section{Referenser}

\section{Litteratur}

Andersson, U., Ohlsson, J., Oscarsson, H. \& Oskarsson, M. (red.) (2017) Larmar och gör sig till. SOM-undersökningen 20I6. Göteborg: SOM-institutet.

Andersson, U., Carlander, A., Lindgren, E. \& Oskarsson, M. (red.) (2018) Sprickor i fasaden. SOM-undersökningen 20I7. Göteborg: SOM-institutet.

Art, D. (2007) "Reacting to the Radical Right: Lessons from Germany and Austria", Party Politics, 13, 3, s. 331-349. DOI: https://doi.org/IO.II77/I354068807075939

Bale, T. (2003) "Cinderella and Her Ugly Sisters. The Mainstream and Extreme Right in Europe's Bipolarising Party Systems", West European Politics, 26, 3, s. 67-90. DOI: https://doi.org/IO.IO80/0I402380312331280598

Bennich-Björkman, L. (2008) "Medborgarsamhället: Politisk kultur och politiskt beteende i Sverige", i Bennich-Björkman, L. \& Blomqvist, P. (red.) Mellan folkhem och Europa. Svensk politik i brytningstid. Malmö: Liber.

Capoccia, G. (200I) "Defending Democracy: Reactions to Political Extremism in Interwar Europe", European Journal of Political Research, 39, 4, s. 43I-460. DOI: https://doi.org/IO.IO23/A:I0I0886614303 
Capoccia, G. (2004) "Defense of Democracy against the Extreme Right in Inter-war Europe: A Past Still Present?", i Eatwell, R. \& Mudde, C. (red.) Western Democracies and the New Extreme Right Challenge. New York: Routledge.

van Donselaar, J. (2003) "Patterns of Response to the Extreme Right in Western Europe" i Merkl, P. \& Weinberg, L. (red.) Right-Wing Extremism in the Twenty-First Century. London: Frank Cass Publishers.

Downs, A. (1957) An Economic Theory of Democracy. New York: Harper and Row.

Downs, W. (200I) "Pariahs in their Midst: Belgian and Norwegian Parties react to Extremist Threats", West European Politics, 24, 3, s. 23-42.

DOI: https://doi.org/I0.IO80/OI402380I0842545I

Downs, W. (2002) "How Effective is the Cordon Sanitaire? Lessons from Efforts to Contain the Far Right in Belgium, France, Denmark and Norway", Journal für Konfliktund Gewaltforschung, 4, I, s. 32-5I.

URL: http://www.uni-bielefeld.de/ikg/jkg/I-2002/downs.pdf (7 mars 2019)

Eatwell, R. (2004) "Introduction: The New Extreme Right Challenge", i Eatwell, R. \& Mudde, C. (red.) Western Democracies and the New Extreme Right Challenge. New York: Routledge.

Esping-Andersen, G. (1990) The Three Worlds Of Welfare Capitalism. Cambridge: Polity. Fryklund, B. \& Peterson, T. (198I) Populism och missnöjespartier i Norden. Lund: Arkiv förlag.

Fryklund, B., Kiiskinen, J. \& Saveljeff, S. (2007) Populism and the Mistrust of Foreigners: Sweden in Europe. Norrköping: Integrationsverket.

Fryklund, B. (2008) "Ett förändrat Sverige: Migrationen och dess konsekvenser", i Bennich-Björkman, L. \& Blomqvist, P. (red.) Mellan folkhem och Europa. Svensk politik i brytningstid. Malmö: Liber.

Fryklund, B. (2015) "Sverige som dubbelt undantag. Radikala högerpopulistiska partier i den ekonomiska, politiska och sociala krisen i Europa”, i Andersson, N. \& Greiff, M. (red.) Från Göteborg till Malmö via Königsberg. En festskrift till Lennart Olausson. Malmö: Malmö högskola.

Fryklund, B. (2018) Populism - Changes over Time and Space in the Nordic Countries 19652015. The Swedish Case as an Ideal Type or Comparative Yardstick for the Development of Populism in the Other Nordic Countries. Jyväskylä: Jyväskylä universitet.

Goodwin, M. (20I4) "A Breakthrough Moment or False Dawn? The Great Recession and the Radical Right in Europe", i Sandelind, C. (red.) European Populism and Winning the Immigration Debate. Stockholm: Fores.

Goldthorpe, J. (2007) On Sociology. Vol. 2. Stanford: Stanford University Press.

Hellström, A. (20Iо) Vi är de goda. Den offentliga debatten om Sverigedemokraterna och deras politik. Hägersten: Tankekraft.

Håkansson, A. (2005) "Vad styr partiers agerande?", i Erlingsson, G. Ó., Håkansson, A., Johansson, K. M. \& Mattson, I. (red.) Politiska partier. Lund: Studentlitteratur. Kiiskinen, J. \& Saveljeff, S. (2010) Att dansa i otakt med väljarna. Socialdemokraternas och Moderaternas strategiska bemötande av Sverigedemokraterna. Malmö: IMER, Malmö högskola. 
Kitschelt, H. (1997) The Radical Right in Western Europe. A Comparative Analysis. Ann Arbour: The University of Michigan Press.

Kohn, H. (1944) The Idea of Nationalism. A Study in Its Origins and Background. New York: MacMillian.

de Lange, S. (2008) From Pariah to Power. The Government Participation of Radical Right-Wing Populist Parties in West European Democracies. Antwerpen: Universiteit Antwerpen.

Marx, P. \& Nguyen, C. (20I8) "Anti-elite Parties and Political Inequality: How Challenges to the Political Mainstream Reduce Income Gaps in Internal Efficacy", European Journal of Political Research, 57, 4, s. 919-940. DoI: https://doi.org/IO.IIII/I475-6765.I2258

Meguid, B. (2005) "Competition Between Unequals: The Role of Mainstream Party Strategy in Niche Party Success", American Political Science Review, 99, 3, s. 347-359. Dor: https://doi.org/I0.1017/So00305540505170I

Meguid, B. (2008) Party Competition between Unequals. Strategies and Electoral Fortunes in Western Europe. Cambridge: Cambridge University Press.

Mouffe, C. (2005) "The 'End of Politics' and the Challenge of Right-wing Populism”, i Panizza, F. (red.) Populism and the Mirror of Democracy. London: Verso.

Mudde, C. (2007) Populist Radical Right Parties in Europe. Cambridge: Cambridge University Press.

Mudde, C. (20I0) "The Populist Radical Right: A Pathological Normalcy", West European Politics, 33, 6, s. II67-II86. DoI: https://doi.org/Io.IO80/0I402382.2010.50890I

Mudde, C. (2013) "Three Decades of Populist Radical Right Parties in Western Europe: So What?", European Journal of Political Research, 52, I, s. I-I9. DOI: https://doi.org/IO.IIII/j.I475-6765.2012.02065.x

Mudde, C. \& Rovira Kaltwasser, C. (2017) Populism. A Very Short Introduction. Oxford: Oxford University Press.

Olin Wright, E. (1997) Class Counts. Comparative Studies in Class Analysis. Cambridge: Cambridge University Press.

Rydgren, J. (2002) "Varför inte i Sverige? Om den radikala högerpopulismens relativa misslyckande", Arkiv för studier i arbetarrörelsens historia, 86-87, s. I-34.

Rydgren, J. (20I7) "Radical Right-Wing Parties in Europe: What's Populism Got to Do With It?", Journal of Language and Politics, I6, 4, s. 485-496. DoI: https://doi.org/IO.I075/jlp.I7024.ryd

Sannerstedt, A. (2008) ”De okända väljarna - en analys av de skånska väljare som röstade på icke riksdagspartier 2006", i Nilsson, L. \& Antoni, R. (red.) Medborgarna, regionen och flernivådemokratin: Skåne 2006. Göteborg: SOM-institutet.

Sannerstedt, A. (20I0) "Sverigedemokraterna i Skåne”, i Johansson, S. (red.), Regional demokrati. Om politik och medier i Skåne. Göteborg: SOM-institutet.

Sannerstedt, A. (2013) "Vem älskar Sverigedemokraterna? En undersökning av partiets sympatisörer i Skåne", i Ohlsson, J. \& Bergström, A. (red.), Vanor och attityder i förändring. Samhälle, opinion och medier i Skåne. Göteborg: SOM-institutet. 
Sannerstedt, A. (20I4) "Sverigedemokraternas sympatisörer", i Bergström, A. \& Oscarsson, H. (red.) Mittfära \& marginal. SOM-undersökningen 2013. Göteborg: SOMinstitutet.

Sannerstedt, A. (2015) "Hur extrema är Sverigedemokraterna?", i Bergström, A., Johansson, B., Oscarsson, H. \& Oskarsson, M. (red.) Fragment. SOM-undersökningen 2014. Göteborg: SOM-institutet.

Saveljeff, S. (20II) New Questions and New Answers. Strategies Towards Parties with Radical Right-Wing Populist Profile. Malmö: IMER, Malmö högskola.

Schain, M., Zolberg, A. \& Hossay, P. (red.) (2002) Shadows over Europe. The Development and Impact of the Extreme Right in Western Europe. New York: Palgrave MacMillan.

Sjöblom, G. (1968) Party Strategies in a Multiparty System. Lund: Studentlitteratur.

Smith, A. D. (1986) The Ethnic Origins of Nations. Oxford: Blackwell.

van Spanje, J. \& van der Brug, W. (2007) "The Party as Pariah: The Exclusion of AntiImmigration Parties and its Effect on their Ideological Positions", West European Politics, 30, 5, s. 1022-1040.

DOI: https://doi.org/I0.I080/OI40238070161743I

Strom, K. (1990) "A Behavioral Theory of Competitive Political Parties", American Journal of Political Science, 34, 2, s. 565-598.

URL: https://www.jstor.org/stable/2III46I

Taggart, P. (1996) The New Populism and the New Politics. New Protest Parties in Sweden in a Comparative Perspective. Basingstoke: Macmillan.

Taggart, P. (2000) Populism. Buckingham: Open University Press.

\section{Övriga källor}

Aftonbladet 4 maj 20I8, "Löfven: Ingen skola för barn som fått nej till asyl”.

URL: https://www.aftonbladet.se/nyheter/samhalle/a/kaG44v/lofven-ingen-skolafor-barn-som-fatt-nej-till-asyl (7 mars 2019)

Aftonbladet 17 maj 20I8, "Kommunalråd kritiska till Löfvens migrationspolitik".

URL: https://www.aftonbladet.se/nyheter/samhalle/a/a2x44A/kommunalrad-

kritiska-till-lofvens-migrationspolitik (7 mars 20I9)

Aftonbladet 24 maj 20I8, "Tunga kritiken från S-veteranerna: Har aldrig låtit så här”. URL: https://www.aftonbladet.se/nyheter/samhalle/a/WLie8g/tunga-kritiken-frans-veteranerna-har-aldrig-latit-sa-har (7 mars 20I9)

Dagens Nyheter 5 september 20I8, "Arbetslinjen och finanskris förklarar SD:s framgångar", Folke, O., Persson, T. \& Rickne, J.

URL: https://www.dn.se/debatt/andra-ej-i-klara-arbetslinjen-och-finanskris-

forklarar-sds-framgangar/ (7 mars 2019)

Moderaterna.se, Integration. URL: https://moderaterna.se/integration (7 mars 20I9)

Sifo-undersökning 2017, Väljarbarometern november 2017.

URL: https://www.kantarsifo.se/rapporter-undersokningar/valjarbarometernnovember-20I7 (7 mars 20I9)

Socialdemokraterna 2018, En trygg migrationspolitik för en ny tid.

URL: https://www.socialdemokraterna.se/aktuellt/20I8/en-trygg-migrationspolitikfor-en-ny-tid/ (7 mars 20I9) 
ARKIV | NR IO | VALET 2018

SVT Valu 2018, SVT:s vallokalsundersökning riksdagsvalet 2018.

URL: https://www.svt.se/omoss/media/filer_public/5c/I7/5ci7fc9I-3Ic4-4eoa-ai7f-

b423I8edf4a4/valuresultat_riksdagsval_pk_20I8_vagda_09I2.pdf (7 mars 20I9)

Sydsvenskan I3 maj 20I8, "Stefan Löfven - folkhemssheriffen", Ohlsson, P. T.

URL: https://www.sydsvenskan.se/20I8-05-I3/folkhemssheriffen (7 mars 2019)

Val digital. URL: https://val.digital/ElectionAnalysis/ (7 mars 20I9)

Valforskningsprogrammets faktablad 2018:15, Varifrån kom Sverigedemokraternas väljare?

Göteborgs universitet.

URL: https://valforskning.pol.gu.se/digitalAssets/I685/I685658_varifr--n-kom-sds-v-ljare.pdf (7 mars 2019) 


\section{Tomas Peterson, Mikael Stigendal \& Björn Fryklund}

\section{Skånepartiet}

Om folkligt missnöje i Malmö

Efter 66 års styre förlorade socialdemokratin makten i Malmö vid valet 1985. Den avgörande faktorn därbakom var framgången för Carl P. Herslows Skåneparti. I denna bok ger tre sociologer en ingående skildring av detta partis och dess ledares säregna utveckling. Författarna gör också en djuplodande analys av partiets sympatisörer och deras samhällspolitiska världsbild.

Arkiv förlag 1988, mjukband, 289 sidor

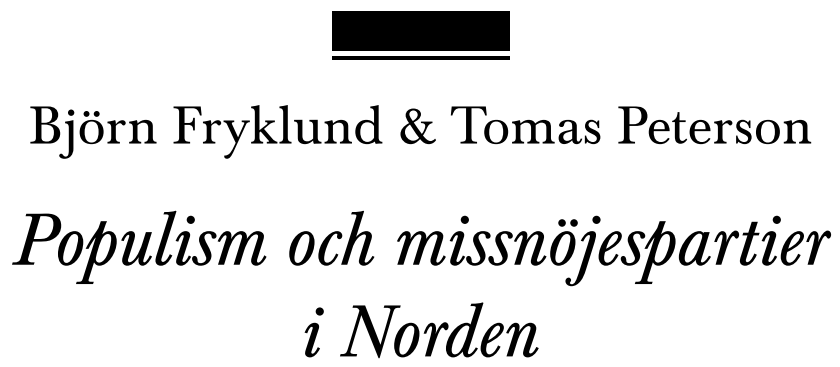

Studier av småborgerlig klassaktivitet

Under de senaste årtiondena har det i de nordiska länderna vuxit fram en ny typ av partier och rörelser, som hämtar sin näring ur ett populistiskt missnöje med det politiska systemet. Mot bakgrund av de fyra nordiska ländernas historia ger författarna en klargörande skildring av dessa rörelsers förutsättningar och betydelse.

Arkiv förlag 1981, mjukband, 470 sidor

»Läs mer om böckerna på www.arkiv.nu« 


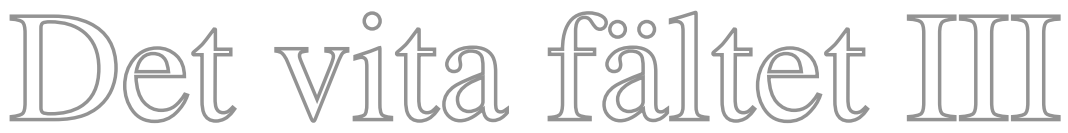

Samtida forskning om högerextremism

Den tredje volymen i serien Det vita fältet öppnar med en kritisk granskning av extremismbegreppet av sociologerna Adrienne Sörbom och Magnus Wennerhag. Markus Lundström och Tomas Lundström introducerar i stället begreppet "radikal nationalism" för att begreppsliggöra det högerextrema politiska projektet under de senaste hundra åren i Sverige. Vidare diskuterar den nederländske forskaren Cas Mudde omfattningen av den våg av högerpopulism som spridits genom Europa. Bristerna inom forskningen om Sverigedemokraterna, och deras kontakter med andra delar av den högerextrema miljön, behandlas av den amerikanske musikvetaren Benjamin Raphael Teitelbaum. Avslutningsvis diskuteras, från tyskt perspektiv, förutsättningarna för ideologiskt betingat våld av Daniel Köhler och Tine Hutzel i två artiklar.

Mats Deland, Paul Fuehrer, Fredrik Hertzberg \& Thomas Hvitfeldt (red.) Specialnummer av Arkiv. Tidskrift för sambällsanalys, nr 52016

\section{„Läs och ladda ner på www.tidskriftenarkiv.se eller via DoI: https://doi.org/I0.13068/2000-6217.5"}

\section{Tidigare volymer i samma serie:}

Det vita failtet

Samtida forskning om högerextremism, Mats Deland m.fl. (red.), i skriftserien Opuscula historica Upsaliensia 2010

URL: http://urn.kb.se/resolve?urn=urn:nbn:se:uu:diva-I39645

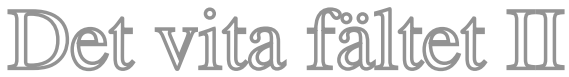

Samtida forskning om högerextremism, specialnummer av Arkiv. Tidskrift för sambällsanalys, $\mathrm{nr} 22013$

DOI: https://doi.org/IO.13068/2000-6217.2 